\title{
THE RENAL CLEARANCE OF ENDOGENOUS "CREATININE" IN MAN
}

\author{
By JAN BROD ${ }^{1}$ AND JONAS H. SIROTA ${ }^{2}$ \\ (From the Departments of Physiology and Medicine, New York University College of \\ Medicine, New York City)
}

(Received for publication May 13, 1948)

The existing methods for the analysis of inulin, as well as the requirements for the continuous intravenous infusion of this material, place the inulin clearance method for measuring the glomerular filtration rate beyond the reach of practicality for many laboratories and in general limit clearance observations to relatively short intervals of time. There is a requirement for a simpler clearance method of at least approximate accuracy by which observations can be made continuously for periods of 24 hours or longer. Endogenous "creatinine" appears to offer possibilities in this direction, since it would obviate the necessity for intravenous infusions, frequent withdrawal of blood and elaborate analytical procedures.

The nature of the endogenous substance or substances which yield color with Jaffe's alkaline picrate reaction for creatinine has long been a matter of controversy. The literature on this subject is reviewed by Miller and Dubos $(1,2)$. These authors, using an allegedly specific enzymatic method on 1:5 plasma filtrates prepared with 10 per cent sodium tungstate and $0.66 \mathrm{~N}$ sulfuric acid, concluded that in normal human plasma, creatinine constitutes 80 to 100 per cent of the chromogenic substance, although in renal disease, where the chromogen is elevated, the plasma may contain relatively large amounts of non-creatinine chromogenic material.

Exogenous creatinine is excreted in man both by glomerular filtration and tubular secretion. Crawford (3) has recently adduced new evidence on this point by showing that the exogenous creatinine/inulin and the exogenous creatinine/thiosulfate clearance ratios are reduced by saturation

\footnotetext{
1 Rockefeller Foundation Fellow; permanent address : Department of Medicine, Charles University Hospital, Prague, Czechoslovakia.

2 Dazian Foundation Fellow; permanent address: Department of Medicine, The Mount Sinai Hospital, New York City.
}

of the tubules with diodrast or p-aminohippuric acid. Although Crawford's control ratios are not as high as those reported by others, the average value as recorded by her and by Shannon (4), Shannon and Ranges (5), McCance and Widdowson (6 to 8), Josephson and Godin (9), and Miller and Winkler (10) appears to be about 1.3, indicating that about 30 per cent of the urinary exogenous creatinine is excreted by the tubules.

Several investigators have reported, however, that the endogenous chromogen/inulin clearance ratio in subjects without renal disease is close to 1.0. Miller and Winkler (10), using the enzymatic method of Miller and Dubos (2), report ratios varying from 0.8 to 1.5 (average 1.07) and exogenous/endogenous chromogen ratios, as determined in successive clearance periods, ranging from 1.1 to 2.0 (average 1.63).

Popper and Mandel (11) report the endogenous chromogen/xylose clearance ratio to be 1.35 , a value comparing favorably with the average inulin/xylose clearance ratio of 1.25 (12), but Popper and Mandel's ratios vary from 0.77 to 4.5 , indicating great uncertainty either in the clearance ratio or in their analytical methods. The method used by Popper and Mandel was that of Popper, Mandel and Mayer (13), in which the plasma proteins were precipitated with picric acid. $^{3}$

Steinitz and Turkänd (15), using Popper, Mandel and Mayer's picric acid filtrate, report a chromogen/inulin clearance ratio for normal subjects ranging from 0.73 to 1.17 (average 1.03). (The exogenous/endogenous chromogen ratio as deter-

\footnotetext{
3 Findley (14) found that the exogenous creatinine clearance in man is independent of plasma concentration only when an endogenous blank of about $0.5 \mathrm{mgm}$. per cent is deducted from the total chromogen value, but the order of magnitude of the correction seems too small to warrant this interpretation. A critical answer in this question can only be obtained by the study of simultaneous clearances.
} 
mined before and after the administration of creatinine in subjects with and without renal disease ranged from 0.92 to 1.87 and averaged 1.22.) Since the normal values obtained with picric acid filtrate lay between 0.5 and $1.0 \mathrm{mgm}$. per cent, while those reported with the Folin tungstate filtrate were 1 to $2 \mathrm{mgm}$. per cent, Steinitz and Turkänd suggested that the picric acid used in precipitation of the proteins precipitates some of the non-creatinine chromogenic substance. However, the figures of 1 to $2 \mathrm{mgm}$. per cent as originally reported by Folin and Denis (16) were obtained with whole blood. The red cells are now known to contain considerable quantities of noncreatinine chromogen. With plasma, the tungstic acid filtrate in our hands yields values varying from 0.64 to $1.10 \mathrm{mgm}$. per cent in subjects without renal disease.

Smith, Finkelstein and Smith (17), using the picric acid filtrate, found an endogenous chromogen/inulin clearance ratio ranging from 1.01 to 1.42 (average 1.19), whereas using the Steiner, Urban and West filtrate $\left(\mathrm{BaCO}_{3}-\mathrm{Fe}_{2}\left[\mathrm{SO}_{4}\right]_{3}\right)$ this ratio ranged from 0.81 to 1.08 and averaged 0.94 . In all cases these ratios were depressed slightly, though scarcely beyond the limits of analytical error, during saturation of the tubules with diodrast. Although both methods of protein precipitation gave quantitative recovery of added creatinine, the endogenous chromogen in the picric acid filtrate from a series of 14 samples of human plasma ranged from 50 to 79.2 (average 66.6) per cent of that present in the iron filtrate. (This discrepancy might in part be due to the greater acidity of the picric acid filtrate.)

In four subjects with renal disease, Miller and Winkler (10) report endogenous chromogen/ inulin clearance ratios of 0.9 to 1.7 (average 1.38) and an exogenous/endogenous chromogen clearance ratio in successive clearance determinations of 1.0 to 1.7 (average 1.3). Similarly Steinitz and Turkänd (15) found that in subjects with glomerulonephritis the endogenous chromogen/inulin clearance ratio ranged from 1.04 to 1.73 (average 1.37).

It appears from the above data that in subjects with reduced filtration rates owing to renal disease the endogenous chromogen clearance substantially exceeds the inulin clearance and therefore affords no reliable index of the filtration rate. However, the average figures on subjects without renal disease indicate that the endogenous chromogen clearance is close to the filtration rate, despite the fact that the variability in the clearance ratio indicates variation in the composition of the chromogen and, as the determinations have hitherto been carried out, the data leave a serious question of reliability in any one subject. Since the methods of determining the endogenous chromogen have differed considerably, it seemed to us that these variations might in part be attributable to differences in technique, and we have therefore reexamined the endogenous chromogen clearance, comparing it with the inulin clearance and the thiosulfate clearance (which Newman, Gilman and Philips [18] have shown to be equal to inulin clearance in man) and in some instances with the mannitol 4 and exogenous creatinine clearances.

\section{METHODS}

Standard renal clearance procedures (22) were utilized. One liter of tap water was administered one to two hours before the beginning of the test. Urine was collected by an in-dwelling catheter and the bladder was rinsed with saline and emptied with air at the end of each urine collection period. Priming and maintenance dosages of test substances were calculated to yield plasma concentrations of 15 to $20 \mathrm{mgm}$. per cent of inulin, 25 to $30 \mathrm{mgm}$. per cent of thiosulfate, 200 to $300 \mathrm{mgm}$. per cent of mannitol, $25 \mathrm{mgm}$. per cent of exogenous creatinine, 2 to $3 \mathrm{mgm}$. per cent of PAH for effective renal plasma flow and 60 mgm. per cent for $T_{\text {m }}$ se.

A control urine $\left(U_{0}\right)$ was collected in each instance to permit the determination of the excretion of blank substances $\left(U_{0} V\right)$, for which correction was made in the calculation of clearances. This blank correction is particularly important where there is reduced renal function. In one of our patients with marked nitrogen retention in whom the filtration rate ranged from 2 to $4 \mathrm{cc}$. per minute the inulinoid blank was 26 per cent and the thiosulfate blank 33 per cent of the quantities excreted during clearance determinations.

The number of urine collection periods varied from three to nine and were usually about ten minutes in dura-

\footnotetext{
4 Several investigators (Berger, Farber and Earle [19] ; Corcoran and Page [20]; Hoobler [21]) have reported that the mannitol clearance as determined with the periodate-chromotropic acid method of Corcoran and Page (20) is some 10 per cent less than the inulin clearance, an observation which has been confirmed in this laboratory, but we include our mannitol data here since they still afford useful evidence on the endogenous chromogen clearance. For the calculation of clearance ratios the mannitol figures are multiplied by 1.10 to approximate the hypothetical inulin clearance.
} 
tion, except when low urine flow required extension to 15 to 20 minutes. Two blood specimens were drawn for each three urine collection periods. Blood concentrations were plotted semilogarithmically against time and mean concentrations estimated by interpolation to a point 2.5 minutes $^{5}$ preceding the midpoint of each collection period.

In six subjects clearances of endogenous chromogen and inulin were studied over a period of 24 to 48 hours. The urine collection periods were four hours in length and urine samples were obtained by voiding. Blood samples were drawn at the midpoint of each urine collection period. The number of periods varied from five to $12 .{ }^{\circ}$

Inulin was determined by a modification of Harrison's method as described by Goldring and Chasis (23), with the exception that $2 \mathrm{cc}$. of undiluted plasma were added to $6 \mathrm{cc}$. of 20 per cent yeast, $1.0 \mathrm{~N} \mathrm{NaOH}$ was substituted for $1.1 \mathrm{NaOH}$ in precipitation, and $\mathrm{B}_{0}$ was determined by adding a known amount of inulin to the $B_{0}$ filtrate. In ten experiments inulin recoveries were performed simultaneously with the analyses and these ranged from 95 to 100.5 per cent with an average of 98.5 per cent.

In initial experiments we obtained only 90 per cent recovery from plasma of added creatinine when using the picric acid precipitation method of Popper, Mandel and Mayer (13). Consequently we turned to different protein precipitation methods. We found a modified FolinWu tungstic acid method, using a 1:4 dilution, best suited to our purposes. Six cc. of plasma were diluted with $6 \mathrm{cc}$. of water and the proteins precipitated by the addition of 6 cc. of 5 per cent $\mathrm{Na}_{2} \mathrm{WO}_{4} \cdot 2 \mathrm{H}_{2} \mathrm{O}$ and 6 cc. of $0.66 \mathrm{~N} \mathrm{H}_{2} \mathrm{SO}_{4}$ added dropwise, the mixture being shaken intermittently and allowed to stand for ten minutes, after which time it was filtered through washed cotton. The recovery of added creatinine was checked by substituting $6 \mathrm{cc}$. of creatinine standard solutions, ranging from 1.0 to $2.5 \mathrm{mgm}$. per cent, for the $6 \mathrm{cc}$. of water. A reference standard was prepared by adding 6 cc. of creatinine standard to $18 \mathrm{cc}$. of water. Six-cc. samples of the filtrates and creatinine standard (in duplicate) were subjected to the Jaffé reaction according to the modification advocated by Bonsnes and Taussky (24). In 25 such determinations, where the endogenous chromogen ranged from 0.72 to $2.48 \mathrm{mgm}$. per cent and the added creatinine from 1 to $2.64 \mathrm{mgm}$. per cent, the recovery averaged 100.2 per cent, with one value of 91.6 and all others lying between 98.5 and 106 per cent.

The quantity of acid used in the above method is twice that usually recommended for the tungstic acid filtrate. The use of $0.33 \mathrm{~N} \mathrm{H}_{2} \mathrm{SO}_{4}$ instead of $0.66 \mathrm{~N} \mathrm{H}_{2} \mathrm{SO}_{4}$ in the $1: 4$ dilution precipitation results in endogenous chro-

5 In view of T. Hilden's recent studies (personal communication) it appears that this figure should be six minutes for a urine flow of 2 to $10 \mathrm{cc}$. per minute.

- We are indebted to Dr. David Baldwin and Dr. Herman Villareal for their assistance with these latter experiments. The details of technique as well as the 24-hour cyclic variation of renal function will be reported elsewhere. mogen values which agree closely with those found in the more acid filtrate, but the recoveries of added creatinine are significantly lower. In a series of six such recoveries the average was close to 90 per cent with extremes of 83.0 and 93.5 per cent.

Thiosulfate was determined by the method of Newman, Gilman and Philips (18). PAH was determined by the method of Smith et al. (25) and mannitol by the method of Corcoran and Page (20). In ten trials the plasma recovery of mannitol using this method ranged from 96.7 to 103.5 per cent, and averaged 99.1 per cent.

The Coleman Jr. spectrophotometer was used for PAH and creatinine determinations and the Evelyn photoelectric colorimeter for mannitol and inulin.

All subjects were patients from the wards of the Third (New York University) Medical or Surgical Services of Bellevue Hospital.

\section{RESULTS}

Endogenous "creatinine" chromogen clearances in individuals without renal disease. The results of observations on 14 subjects without renal disease are summarized in Table I. The individuals studied are in the younger adult and middle-aged groups. The plasma concentrations of the test substances were all in the proper range and were usually declining slightly throughout the period of observation, except for endogenous chromogen which remained practically constant in any one individual. The endogenous chromogen plasma concentration ranged from 0.64 to $1.10 \mathrm{mgm}$. per cent, with an average of $0.91 \mathrm{mgm}$. per cent.

The endogenous chromogen/inulin clearance ratios in these subjects ranged from 0.88 to 1.10 with an average in 94 clearance periods of $1.00 \pm$ 0.018. Except for subjects No. 7 and No. 11 agreement between the two clearances was uniformly good, not only in the average but also in single urine collection periods. In the two cases mentioned the endogenous chromogen clearances averaged 10 per cent higher and 12 per cent lower, respectively, than the inulin clearances. With subject No. 7, the 10 per cent disparity may in part be attributable to analytical errors in the inulin clearance, since the simultaneous thiosulfate clearances averaged only 4 per cent lower than the endogenous chromogen clearances. Simultaneous thiosulfate clearances were not performed in subject No. 11. The endogenous chromogen/thiosulfate clearance ratios in seven subjects ranged from 0.84 to 1.01 and averaged $0.95 \pm 0.018$ representing a total of 47 clearance periods. 
TABLE I

Comparison of simultaneous endogenous "creatinine" chromogen, inulin and thiosulfate clearances in patients with normal renal function

\begin{tabular}{|c|c|c|c|c|c|c|c|c|c|c|c|c|c|c|c|}
\hline \multirow{3}{*}{ No. } & \multirow{3}{*}{ 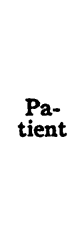 } & \multirow{3}{*}{ Sex } & \multirow{3}{*}{ Age } & \multirow{3}{*}{ Diagnosis } & \multirow{3}{*}{$\begin{array}{c}\text { No. } \\
\text { of } \\
\text { pe- } \\
\text { riods }\end{array}$} & \multicolumn{3}{|c|}{$\begin{array}{l}\text { Mean plasma } \\
\text { concentration }\end{array}$} & \multicolumn{3}{|c|}{ Plasma clearance* } & \multicolumn{4}{|c|}{ Clearance ratios } \\
\hline & & & & & & \multirow{2}{*}{ Inulin } & \multirow{2}{*}{ |"Creat." } & \multirow{2}{*}{ Thio. } & \multirow{2}{*}{ Inulin } & \multirow{2}{*}{ "Creat." } & \multirow{2}{*}{ Thio. } & \multicolumn{2}{|c|}{$\frac{\text { "Creatinine" }}{\text { inulin }}$} & \multicolumn{2}{|c|}{$\frac{\text { "Creatinine" }}{\text { thio. }}$} \\
\hline & & & & & & & & & & & & Average & Range & Average & Range \\
\hline 1 & H. K. & $\mathbf{M}$ & 57 & Psychoneurosis & 3 & $\mid \begin{array}{c}m g m . l \\
100 \\
20.0 .\end{array}$ & $\begin{array}{c}\begin{array}{c}m g m . l \\
100 \\
c c .\end{array} \\
1.08\end{array}$ & $\begin{array}{l}m g m . / \\
100 \text { cc. }\end{array}$ & $\begin{array}{c}c c . / \\
\min . \\
87.6\end{array}$ & $\begin{array}{l}\text { cc. } / \mathrm{min} . \\
83.0\end{array}$ & $\begin{array}{l}c c . l \\
\text { min. }\end{array}$ & 0.95 & 0.90 & & \\
\hline 2 & S. J. & F & 23 & $\begin{array}{l}\text { Alcoholic } \\
\text { gastritis }\end{array}$ & 4 & 23.0 & 0.96 & 29.0 & 95.6 & 99.5 & 103 & 1.00 & $\begin{array}{l}0.98 \\
1.01\end{array}$ & 1.01 & $\begin{array}{l}0.93 \\
1.02\end{array}$ \\
\hline 3 & C. L. & $\mathbf{M}$ & 42 & Convalescent & 7 & 17.0 & 0.80 & 19.5 & 147.0 & 141.0 & 147 & 1.00 & 0.90 & 0.96 & 0.90 \\
\hline 4 & J. 0. & $\mathbf{M}$ & 52 & Convalescent & 7 & 22.5 & 0.66 & 22.5 & 133.0 & 135.0 & 138 & 1.02 & $\begin{array}{l}0.96 \\
1.05\end{array}$ & 0.97 & $\begin{array}{l}0.89 \\
1.06\end{array}$ \\
\hline 5 & J. H. & $\mathbf{M}$ & 20 & Psychopathic & 9 & 24.1 & 1.10 & 24.4 & 112.0 & 120.0 & 128 & 1.08 & 1.02 & 0.96 & 0.92 \\
\hline 6 & J. H. & $\mathbf{M}$ & 37 & Normal & 7 & 19.8 & 0.88 & 17.5 & 111.0 & 114.0 & 131 & 1.02 & 0.99 & 0.90 & 0.88 \\
\hline 7 & J. H. & $\mathbf{M}$ & 31 & (petit mal) & 6 & 27.3 & 1.04 & 25.5 & 94.7 & 104.0 & 109 & 1.10 & 1.06 & 0.96 & 0.93 \\
\hline 8 & T. R. & $\mathbf{M}$ & 44 & $\begin{array}{c}\text { Convalescent } \\
\text { pneumonia }\end{array}$ & 6 & 22.0 & 0.70 & 18.9 & 121.0 & 115.0 & 135 & & $\begin{array}{l}0.93 \\
0.96\end{array}$ & 0.84 & $\begin{array}{l}0.81 \\
0.91\end{array}$ \\
\hline 9 & F. N. & $\mathbf{M}$ & 35 & Normal & 6 & 18.5 & 0.88 & & 125.0 & 120.0 & & 0.96 & 0.91 & & \\
\hline 10 & G. W. & $\mathbf{M}$ & 24 & Postoperative & 5 & 9.0 & 1.00 & & 147.0 & 154.0 & & 1.05 & 0.99 & & \\
\hline 11 & J. C. & $\mathbf{M}$ & 20 & Lymphopathia & 8 & 11.2 & 0.92 & & 138.0 & 119.0 & & 0.88 & 0.81 & & \\
\hline 12 & P. R. & $\mathbf{M}$ & 28 & Healing pelvic & 6 & 11.5 & 0.64 & & 158.0 & 152.0 & & 1.01 & 0.95 & & \\
\hline 13 & D. W. & $\mathbf{M}$ & 22 & Hyperhydrosis & 8 & 13.5 & 1.00 & & 114.0 & 113.0 & & 0.99 & $\begin{array}{l}1.00 \\
0.94\end{array}$ & & \\
\hline \multirow[t]{2}{*}{14} & G. F. & $\mathbf{M}$ & 33 & Alcoholic & 12 & 15.0 & 1.08 & & 123.0 & 121.0 & & 0.99 & $\begin{array}{l}0.93 \\
1.10\end{array}$ & & \\
\hline & & & & Total & 94 & & & & & \multicolumn{2}{|c|}{ Average } & $\begin{array}{c}1.00 \\
\pm .018\end{array}$ & Average & $\begin{array}{c}0.95 \\
\pm .018\end{array}$ & \\
\hline
\end{tabular}

* All clearance figures are corrected for a body surface area of 1.73 sq. meters.

Endogenous "creatinine" chromogen clearances in individuals with renal disease. Data from 13 subjects with renal disease are presented in Table II. Three had chronic glomerulonephritis; two, acute glomerulonephritis; three, essential hypertension; two, chronic pyelonephritis; two, diabetes associated with albuminuria; and one, disseminated lupus erythematosis with hematuria. The endogenous chromogen levels ranged from 0.80 to $15.1 \mathrm{mgm}$. per cent, and the inulin plasma clearances varied from 97 down to $3 \mathrm{cc}$. per minute.

Exclusive of subject No. 12 the endogenous chromogen/inulin clearance ratios ranged from 0.89 to 1.25 with an average in 57 periods of $1.04 \pm 0.109$. In this group a discrepancy between the two clearance values of 10 per cent or greater generally appears in subjects with filtra- tion rates below $40 \mathrm{cc}$. per minute. However, in such subjects the absolute differences in the clearance values are of such a small magnitude as to leave the endogenous chromogen clearance a clinically useful test approximating the filtration rate. A single exception to this statement is represented by subject No. 12, a young woman in the nephrotic stage of chronic glomerulonephritis; her inulin, thiosulfate and endogenous chromogen clearances in six periods were $38.8,39.2$ and $62.6 \mathrm{cc} . / \mathrm{min}$., respectively, with an endogenous chromogen/ inulin clearance ratio of 1.61 . This last value was checked after five weeks and the clearance ratio was 1.65 .

The thiosulfate clearances revealed wider fluctuations from the endogenous chromogen clearances both in the average and in individual pe- 
TABLE II

Comparison of simultaneous endogenous "creatinine" chromogen, inulin and thiosulfate clearances in patients with renal disease

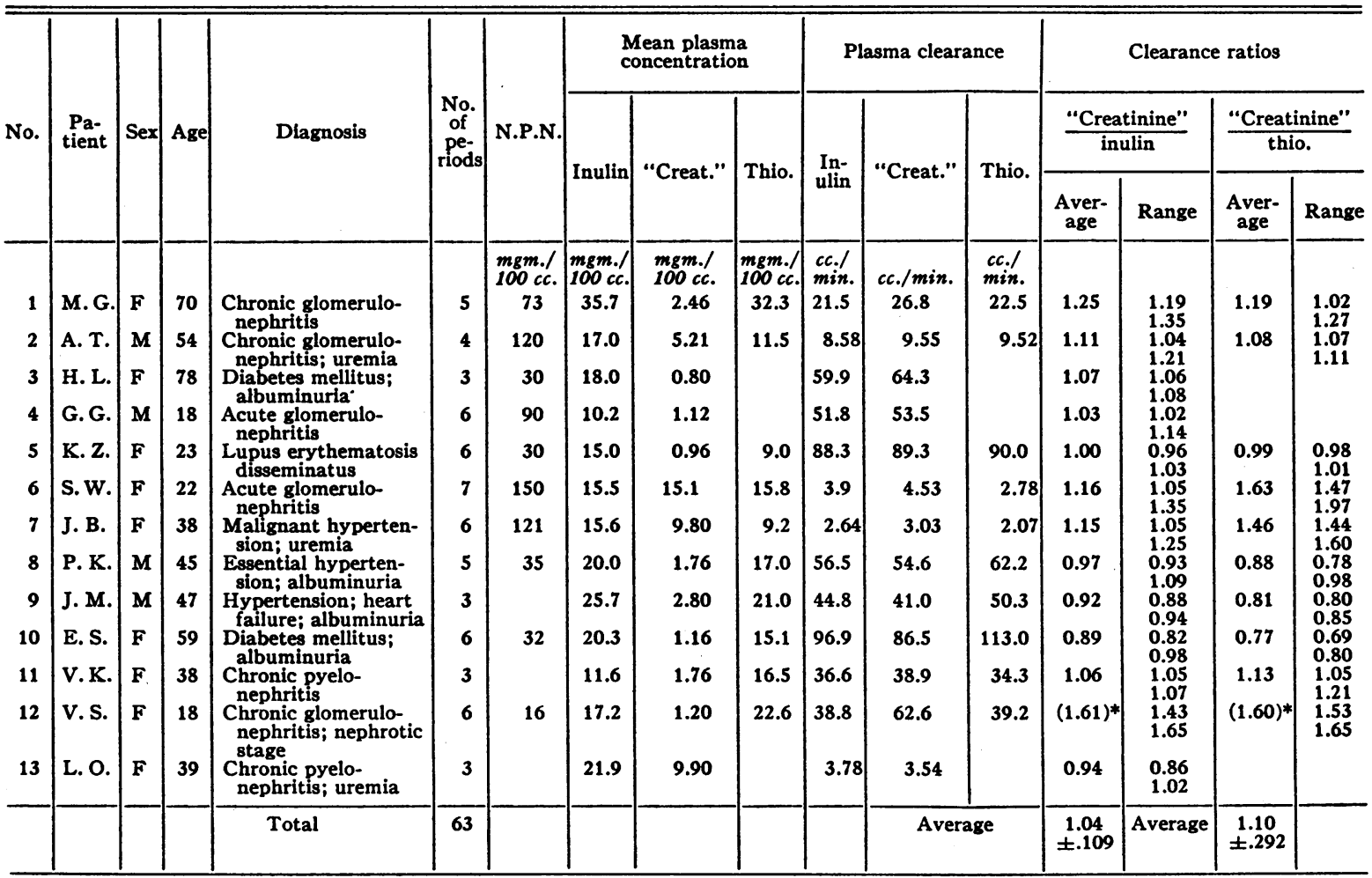

* Omitted from averages.

TABLE III

$\frac{\text { Endogenous "creatinine" chromogen }}{\text { mannitol }}$ clearance ratios compared with successive $\frac{\text { exogenous creatinine }}{\text { mannitol }}$ clearance ratios *

\begin{tabular}{|c|c|c|c|c|c|c|c|c|c|c|}
\hline \multirow{2}{*}{ Patient } & \multirow{2}{*}{ No. } & \multirow[b]{2}{*}{ Sex } & \multirow{2}{*}{ Age } & \multirow{2}{*}{ Diagnosis } & \multicolumn{4}{|c|}{ Plasma clearance } & \multicolumn{2}{|c|}{ Clearance ratiosł } \\
\hline & & & & & $\begin{array}{l}\text { Endog. } \\
\text { creat. }\end{array}$ & Mannitol & $\begin{array}{l}\text { Exog. } \\
\text { creat. }\end{array}$ & Mannitol & $\frac{\text { Endog. creat. }}{\text { Mannitol }}$ & $\frac{\text { Exog. creat. }}{\text { Mannitol }}$ \\
\hline $\begin{array}{l}\text { M. M. } \\
\text { M. W. } \\
\text { A. D. } \\
\text { R. B. }\end{array}$ & $\begin{array}{l}1 \\
2 \\
3 \\
4\end{array}$ & $\begin{array}{l}\mathbf{F} \\
\mathbf{F} \\
\mathbf{F} \\
\mathbf{F}\end{array}$ & $\begin{array}{l}44 \\
30 \\
60 \\
22\end{array}$ & $\begin{array}{l}\text { Osteoarthritis } \\
\text { Bronchitis } \\
\text { Neuralgia } \\
\text { Bronchial } \\
\text { asthma }\end{array}$ & $\begin{array}{r}c c . / m i n . \\
91.1 \\
102.0 \\
85.1 \\
101.0\end{array}$ & $\begin{array}{r}c c . / \min . \\
83.3 \\
104.0 \\
85.2 \\
120.0\end{array}$ & $\begin{array}{c}c c . / \min . \\
113.0 \\
207.0 \\
119.0 \\
168.0\end{array}$ & $\begin{array}{r}c c . / \min . \\
78.1 \\
115.0 \\
78.7 \\
116.0\end{array}$ & $\begin{array}{l}0.99 \\
0.89 \\
0.91 \\
0.77\end{array}$ & $\begin{array}{l}1.32 \\
1.64 \\
1.37 \\
1.32\end{array}$ \\
\hline V. K.† & 5 & $\mathbf{F}$ & 38 & $\begin{array}{l}\text { Chronic } \\
\text { pyelone- }\end{array}$ & 38.9 & 36.6 & 43.5 & 35.8 & 1.06 & 1.21 \\
\hline \multirow[t]{2}{*}{ K. Z.t } & 6 & $\mathbf{F}$ & 23 & $\begin{array}{l}\text { phritis } \\
\text { Disseminated } \\
\text { lupus ery- } \\
\text { thematosis }\end{array}$ & 89.3 & 88.3 & 92.2 & 74.4 & 1.01 & 1.24 \\
\hline & & & & & & & & Average & 0.94 & 1.35 \\
\hline
\end{tabular}

* All clearance figures represent the averages of at least three clearance periods.

$\dagger$ Inulin instead of mannitol was used in these cases. The figures in the mannitol columns therefore represent inulin clearances.

† These ratios are expressed as $\frac{\text { creatinine }}{1.10 \times \text { mannitol }}$ in order to make the figures comparable to the $\frac{\text { creatinine }}{\text { inulin }}$ ratios of patients V. K. and K. Z. 
JAN BROD AND JONAS H. SIROTA

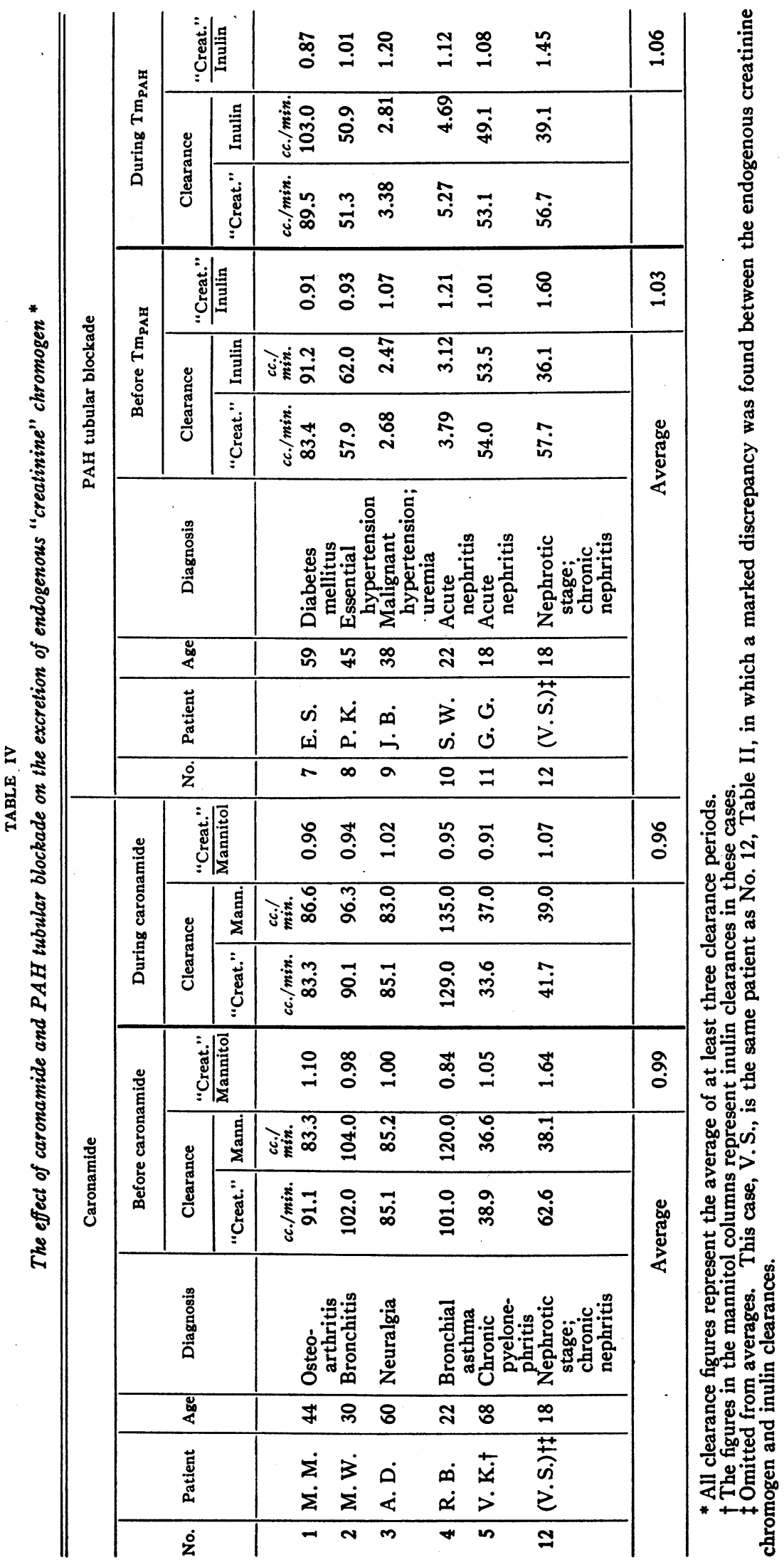


riods, than did the inulin clearances. The average endogenous chromogen/thiosulfate ratio in 51 periods was $1.10 \pm 0.292$ with extremes ranging from 0.77 to 1.63 . We believe this wide fluctuation is in part attributable to technical and analytical errors related to the use of relatively low thiosulfate blood levels in the presence of nitrogen retention, where the blood and urine thiosulfate blanks, as measured by the Newman, Gilman and Philips method (18), may be markedly elevated.

Exogenous creatinine clearances. The results of simultaneous clearances of exogenous creatinine and mannitol in four normal subjects, and of exogenous creatinine and inulin in two subjects with renal disease, are presented in Table III. These values are compared with endogenous chromogen and mannitol clearances determined just prior to the administration of exogenous creatinine. Our observations confirm those of Shannon (4), Miller and Winkler (10), McCance and Widdowson (6 to 8), Crawford (3), and others; namely, that the exogenous creatinine clearance is considerably in excess of the inulin clearance. Thus, the exogenous creatinine $/ 1.10 \times$ mannitol clearance ratio averaged 1.44 as compared to a ratio of 0.94 for endogenous chromogen/mannitol.

The effect of caronamide and tubular blockade by sodium p-aminohippurate on endogenous chromogen clearances. Caronamide ${ }^{7}$ (4-carboxyphenylmethanesulfonanilide) has been shown by Beyer and his coworkers (26) to block the tubular ex-

7 Caronamide (Staticin) was kindly supplied by Sharp and Dohme. cretion of penicillin, phenol red, diodrast and $\mathrm{PAH}$, and the recent studies of Earle and Brodie (27) show that this may be attributable to the fact that caronamide is itself excreted by the tubules. The data in Table IV indicate that, exclusive of subject No. 12, no significant depression of the endogenous chromogen clearances followed the administration of caronamide in doses of 2 grams every four hours for a total of eight doses prior to observation. The average change of the endogenous chromogen/mannitol clearance ratios following caronamide was -3 per cent.

In contrast to the finding of Crawford (3) that the exogenous creatinine/inulin clearance ratio is consistently reduced by saturation of the tubules with p-aminohippurate, the endogenous chromogen/inulin ratio is, in our experience, not significantly changed during $\mathrm{Tm}_{\mathrm{PAH}}$ measurement as compared with control periods (second half of Table IV). The average change of this ratio during $\mathrm{Tm}_{\mathrm{PAB}}$, exclusive of subject No. 12, was +3 per cent. The failure of caronamide and $\mathrm{p}$ aminohippurate to depress this ratio indicates that there is no significant tubular excretion of the endogenous chromogen in the subjects tested.

In subject No. 12, on the other hand, who consistently showed control endogenous chromogen/ inulin clearance ratios of about 1.61 , the ratio was depressed to 1.07 following administration of caronamide, and to 1.45 during $\mathrm{Tm}_{\mathrm{PAB}}$. This depression indicates that in this patient the endogenous chromogen was excreted in a manner similar to exogenous creatinine, namely, by tubular excretion as well as glomerular filtration.

TABLE $v$

Comparison of simultaneous endogenous creatinine chromogen and mannitol clearances in infants

\begin{tabular}{|c|c|c|c|c|c|c|c|c|}
\hline \multirow{2}{*}{ No. } & \multirow{2}{*}{ Patient } & \multirow{2}{*}{ Age } & \multirow{2}{*}{ Diagnosis } & \multirow{2}{*}{$\begin{array}{l}\text { Number of } \\
\text { periods }\end{array}$} & \multirow{2}{*}{$\begin{array}{l}\text { Creatinine } \\
\text { plasma con- } \\
\text { centration }\end{array}$} & \multicolumn{2}{|c|}{ Plasma clearance } & \multirow{2}{*}{$\begin{array}{c}\begin{array}{c}\text { Clearance } \\
\text { ratio* }\end{array} \\
\frac{\text { Creatinine }}{\text { mannitol }}\end{array}$} \\
\hline & & & & & & Creatinine & Mannitol & \\
\hline \multirow[t]{2}{*}{$\begin{array}{l}1 \\
2 \\
3 \\
4\end{array}$} & $\begin{array}{l}\text { M. B. } \\
\text { C. S. } \\
\text { R. W. } \\
\text { J. H. }\end{array}$ & $\begin{array}{r}\text { mos. } \\
2 \\
24 \\
2 \\
25\end{array}$ & $\begin{array}{l}\text { Normal } \\
\text { Mongolian idiot } \\
\text { Normal } \\
\text { Normal }\end{array}$ & $\begin{array}{l}6 \\
6 \\
6 \\
6\end{array}$ & $\begin{array}{c}m g m . / 100 c c \\
0.56 \\
0.68 \\
0.60 \\
0.44\end{array}$ & $\begin{array}{c}c c . / \min . \\
26.5 \\
14.9 \\
10.5 \\
28.7\end{array}$ & $\begin{array}{c}c c . / \min . \\
40.6 \\
24.6 \\
16.4 \\
37.8\end{array}$ & $\begin{array}{l}0.59 \\
0.55 \\
0.58 \\
0.69\end{array}$ \\
\hline & & & & & & & Average & 0.60 \\
\hline
\end{tabular}

*These figures are expressed as $\frac{\text { creatinine }}{1.10 \times \text { mannitol }}$ since cited evidence points to $1.10 \times$ mannitol clearance as being approximately equivalent to the inulin clearance. 
Endogenous chromogen clearances in infants. The results obtained with four infants are tabulated in Table V. ${ }^{8}$ The endogenous chromogen/ $1.10 \times$ mannitol clearance ratios ranged from 0.55 to 0.69 , with an average of 0.60 . The plasma levels of endogenous chromogen were low, ranging from 0.44 to $0.68 \mathrm{mgm}$. per cent, with an average of $0.57 \mathrm{mgm}$. per cent. It appears that the chromogen has a different composition, or is excreted by the kidney in a different manner, in infants than in adults.

\section{DISCUSSION}

Our data indicate that the endogenous "creatinine" chromogen clearance may be used as an index of the filtration rate in normal adults, and as a useful clinical approximation in subjects with renal disease. We recognize that the chromogen is certainly not entirely creatinine, since it is excreted in a different manner than is exogenous creatinine, and that it probably represents more than one substance, its composition possibly varying from time to time. In view of this fact, and in view of the discrepancy between the chromogen clearance and the inulin clearance in subjects with renal disease, we do not advocate the use of the chromogen clearance for precise studies, even in normal subjects; but we do believe that many renal clearance problems, especially protracted studies, can be expedited by its use. It is, moreover, a useful clinical tool for the general evaluation of renal disease. The time required for the analyses of specimens obtained from six clearance periods using endogenous "creatinine" is from one to one and one-half hours, as compared with five to six hours for the same number of samples using inulin. The major difficulties in the inulin technique, namely, maintaining a constant plasma level and reliance on short urine collection periods, are obviated by its use. The chromogen plasma concentration remains fairly constant over a 24-hour period, and urine collection may be prolonged for several hours and thus reduce errors in urine collection at normal urine flows. The method thus lends itself to the study of the 24-hour variations in the filtration rate (29,

\footnotetext{
$8 \mathrm{We}$ are indebted to West, Chasis and Smith (28) for permitting us to use their data on the mannitol clearances in these infants.
}

30). The procedure may be safely used in patients with heart failure, without danger of pulmonary edema induced by the administration of intravenous fluids.

The chromogen clearance is superior to the urea clearance in that it more closely approximates the filtration rate, the analytical procedure is simpler, and in our data the clearance apparently does not depend on the urine flow. We have not investigated the effects on the endogenous chromogen clearance of conditions in which there is excessive protein breakdown, such as may occur in association with malignant growths, starvation, hyperthermia, tuberculosis, hyperthyroidism, leukemia, muscular dystrophies, etc., nor has the effect of a high protein diet, which is known to raise the plasma creatinine level (30), been investigated.

The method is not applicable to the estimation of the filtration rate in infants, as is evidenced by the average endogenous chromogen $/ 1.10 \times$ mannitol clearance ratio of 0.60 . Mannitol/inulin clearance ratios in infants are the same as in adults, namely, averaging 0.90 (31). It is of interest in this connection that McCance (32) found that exogenous creatinine/inulin clearance ratios in infants are close to unity.

The plasma concentration of endogenous chromogen seems to have no definite relationship to the mechanism of excretion. In one subject with uremia in whom the plasma level of chromogen was as high as $9.9 \mathrm{mgm}$. per cent, the chromogen/ inulin clearance ratio averaged 0.94 , whereas in the subject in whom a ratio of 1.61 was observed (No. 12, Table II), the plasma concentration was only $1.2 \mathrm{mgm}$. per cent.

\section{CONCLUSIONS}

1. The endogenous "creatinine" chromogen/ inulin clearance ratio has been determined in 94 and the endogenous chromogen/thiosulfate clearance ratio in 47 simultaneous clearance periods in 14 subjects without renal disease and with normal glomerular filtration rates. The respective ratios averaged $1.00 \pm 0.018$ with a range of 0.88 to 1.10 , and $0.95 \pm 0.018$ with a range of 0.84 to 1.01 .

2. The endogenous chromogen/inulin clearance ratio has been determined in 57 and the endogenous chromogen/thiosulfate clearance ratio in 51 
simultaneous clearance periods in 13 subjects with reduced glomerular filtration rates due to renal disease. In 12 of the 13 subjects the respective ratios averaged $1.04 \pm 0.109$ with a range of 0.89 to 1.25 , and $1.10 \pm 0.292$ with a range of 0.77 to 1.63. A discrepancy between the inulin and chromogen clearances of 10 per cent or greater appeared only in those cases with filtration rates below $40 \mathrm{cc} . / \mathrm{min}$. However, the absolute magnitude of differences between the two clearance values is of such a low order as to permit the chromogen clearance to be used as a clinical test of the glomerular filtration rate in the adult, even with marked impairment of renal function.

3. The sole marked discrepancy between the endogenous chromogen and inulin clearances occurred in a young female in the nephrotic stage of glomerulonephritis. In this instance the chromogen was excreted in a manner similar to exogenous creatinine. The chromogen/inulin clearance ratio averaged 1.61 .

4. In infants the chromogen clearance is significantly lower than simultaneous mannitol clearances. The average chromogen/mannitol ratio, representing 24 periods, was $0.60 \pm 0.066$ with a range of 0.55 to 0.69 .

5. Two grams of caronamide, orally, every four hours for eight doses to six subjects, and an infusion of PAH of sufficient concentration to maintain plasma levels of about $60 \mathrm{mgm}$. per cent in an additional six subjects, had no effect on the chromogen/inulin clearance ratio. However, caronamide in the above doses lowered the chromogen/inulin clearance ratio from 1.61 to 1.07 in the one subject exhibiting a marked discrepancy between the two clearances, providing additional evidence for tubular secretion of the chromogen in this subject.

\section{BIBLIOGRAPHY}

1. Miller, B. F., and Dubos, R., Studies on the presence of creatinine in human blood. J. Biol. Chem., 1937, 121, 447.

2. Miller, B. F., and Dubos, R., Determination by a specific enzymatic method of the creatinine content of blood and urine from normal and nephritic individuals. J. Biol. Chem., 1937, 121, 457.

3. Crawford, B., Depression of the exogenous creatinine/ inulin or thiosulfate clearance ratios in man by diodrast and p-aminohippuric acid. J. Clin. Invest., 1948, 27, 171.
4. Shannon, J. A., The renal excretion of creatinine in man. J. Clin. Invest., 1935, 14, 403.

5. Shannon, J. A., and Ranges, H. A., On the renal tubular excretion of creatinine in normal man. $\mathrm{J}$. Clin. Invest., 1941, 20, 169.

6. McCance, R. A., and Widdowson, E. M., Alkalosis with disordered kidney functions. Lancet, 1937, 2, 247.

7. McCance, R. A., and Widdowson, E. M., The secretion of urine in man during experimental salt deficiency. J. Physiol., 1937, 91, 222.

8. McCance, R. A., and Widdowson, E. M., Functional disorganization of the kidney in disease. $\mathrm{J}$. Physiol., 1939, 95, 36.

9. Josephson, B., and Godin, A. S., Determination of glomerular filtration; inulin and creatinine clearance. Nord. Medic., 1943, 18, 893.

10. Miller, B. F., and Winkler, A. W., The renal excretion of endogenous creatinine in man. Comparison with exogenous creatinine and inulin. J. Clin. Invest., 1938, 17, 31.

11. Popper, H., and Mandel, E., Filtrations und Resorptionleistung in der Nierenpathologie. Ergebnd. inn. Med. u. Kinderh., 1937, 53, 685.

12. Shannon, J. A., and Smith, H. W., The excretion of inulin, xylose and urea by normal and phlorizinized man. J. Clin. Invest., 1935, 14, 393.

13. Popper, H., Mandel, E., and Mayer, H., Zur Kreatininbestimmung im Blute. Biochem. Ztschr., 1937, 291, 354.

14. Findley, T., Jr., The excretion of endogenous "creatinine" by the human kidney. Am. J. Physiol., 1938, 123, 260.

15. Steinitz, K., and Turkänd, $H$., The determination of the glomerular filtration by the endogenous creatinine clearance. J. Clin. Invest., 1940, 19, 285.

16. Folin, O., and Denis, W., On the creatinine and creatine content of blood. J. Biol. Chem., 1914, 17, 487.

- 17. Smith, W. W., Finkelstein, N., and Smith, H. W., Renal excretion of hexitols (sorbitol, mannitol and dulcitol) and their derivatives (sorbitan, isomannide and sorbide) and of endogenous creatinine-like chromogen in dog and man. J. Biol. Chem., 1940, $135,231$.

18. Newman, E. V., Gilman, A., and Philips, F. S., The renal clearance of thiosulfate in man. Bull. Johns Hopkins Hosp., 1946, 79, 229.

19. Berger, E. Y., Farber, S. J., and Earle, D. P., Jr., Renal excretion of mannitol. Proc. Soc. Exper. Biol. \& Med., 1947, 66, 62.

20. Corcoran, A. C., and Page, I. H., A method for the determination of mannitol in plasma and urine. $\mathrm{J}$. Biol. Chem., 1947, 170, 165.

21. Hoobler, S. W., Personal communication, 1947.

22. Smith, H. W., Golding, W., and Chasis, H., The measurement of the tubular excretory mass, effective blood flow and filtration rate in the normal human kidney. J. Clin. Invest., 1938, 17, 263. 
23. Goldring, W., and Chasis, H., Hypertension and $\mathbf{H y}$ pertensive Disease. The Commonwealth Fund, New York, N. Y., 1944.

24. Bonsnes, R. W., and Taussky, H. H., On the colorimetric determination of creatinine by the Jaffe reaction. J. Biol. Chem., 1945, 158, 581.

25. Smith, H. W., Finkelstein, N., Aliminosa, L., Crawford, B., and Graber, M., The renal clearances of substituted hippuric acid derivatives and other aromatic acids in dog and man. J. Clin. Invest., 1945, 24, 388.

26. Beyer, K. H., Russo, H. F., Patch, E. A., Tillson, E. K., and Shaner, G., Certain pharmacologic properties of $4^{\prime}$-carboxyphenylmethanesulfonanilide (caronamide) including its effects on the renal clearance of compounds other than penicillin. J. Pharmacol. \& Exper. Therap., 1947, 91, 272.

27. Earle, D. P., Jr., and Brodie, B. B., The renal excretion of 4'-carboxyphenylmethane sulfonanilide (caronamide). J. Pharmacol. \& Exper. Therap., 1947, 91, 250.

$\div$ 28. West, J. R., Smith, H. W., and Chasis, H., Glomerular filtration rate, effective renal blood flow and maximal tubular excretory capacity in infancy. $\mathrm{J}$. Pediatrics, 1948, 32, 10.

29. Popper, H., and Brod, J., Die Physiologischen Schwankungen der Nierenarbeit. Ztschr. f. klin. Med., 1938, 134, 196.

30. Brod, J., Klincský význam filtrace a resorpce v ledvinách. (Clinical significance of filtration and reabsorption in the kidneys.) Čas. lék. čes., 1946, $85,1315$.

31. Barnett, H. L., McNamara, H., Hare, R. S., and Hare, K., Inulin, urea, mannitol and PAH clearance ratios in premature infants. Fed. Proc., 1948, $7,5$.

32. McCance, R. A., Inulin, diodone, creatinine and urea clearances in newborn infants. J. Physiol., 1947, 106, 431. 